\title{
RESEARCH THE CRISIS INDICATORS IMPACT OF THE SOCIO-ECONOMIC CHARACTER ON THE ENSURING OF THE STATE SECURITY
}

\author{
Serhii Bielai ${ }^{1}$, Dmytro Korniienko이 $^{2}$, Oleksandr Kotukha ${ }^{3}$
}

\begin{abstract}
The conditions of globalization put forward new threats to the existence of the traditional way of life. At present, poverty of the population, considerable property differentiation, lack of middle class, and low level and quality of life in the Ukrainian society are especially dangerous and threatening crisis phenomena of socioeconomic character in Ukrainian society. This fact confirms the statistics of criminal offenses in the sphere of providing the basis of state security, as well as in the field of providing public services, economic activities, and property crimes. Thus, all this, undoubtedly, actualizes the study of the issue of ensuring Ukraine's state security from threats of socio-economic nature. Providing state security is in the sight of a large number of leading scientists. Note that in this case, the study of the crisis phenomena of the socio-economic nature itself and their impact on the provision of state security has not been given sufficient attention. Therefore, the subject of the study is the definition of the methodology of the impact of crisis phenomena of a socio-economic nature on the state of ensuring the state security of Ukraine to develop a model for the emergence and impact of crisis phenomena of a socio-economic nature on the state of state security. Let's mention that sufficient attention is not paid to the research of crisis phenomena of socio-economic nature and their impact on the maintenance of state security. Methodology. To determine the theoretical and methodological principles of crisis phenomena in Ukrainian society, to study the state of ensuring the state security of Ukraine, and to develop a model of the emergence and impact of crisis phenomena of a socio-economic nature on the state of security, functional provisions of the theory of state administration, social economics, economic theory, system analysis, and also a collection of other general scientific and special methods are used, namely: systematization of legal acts, structural analysis, historical method, method of comparative analysis, welfare theory, hypothesis, induction and deduction, analysis and synthesis, structuring and organizational modelling. Practical implications. The emergence of crisis phenomena with a socio-economic component requires governments to make timely and effective management decisions. Such phenomena take central place among the threats to society in the system of ensuring state security. The main crisis phenomena of socio-economic character in Ukraine are identified as high levels of corruption, high levels of poverty, significant property differentiation of the population, social inequality, and lack of a middle class. The analysis of crisis phenomena shows that the most acute, mass, and socially dangerous crisis phenomena are caused by low living standards and unresolved social problems. They are the basis of grave social conflicts between the people and the authorities. There is a developed model of the emergence and impact of the crisis phenomena of a socio-economic nature on the state and shows that today the study of threats to state security, which arose on the socio-economic basis, deserves special attention. The most expedient and relevant is the study of the crisis phenomena of the socioeconomic nature and the development of mechanisms for state regulation of these phenomena.
\end{abstract}

Key words: state security, crisis phenomena of socio-economic origin, socio-economic system, social tension, modelling.

JEL Classification: D63, D74

\footnotetext{
Corresponding author:

${ }^{1}$ Kyiv Faculty of the National Academy of the National Guard of Ukraine, Ukraine.

E-mail: belwz3@ukr.net

${ }^{2}$ Kyiv Faculty of the National Academy of the National Guard of Ukraine, Ukraine.

E-mail: korniienko@ukr.net

${ }^{3}$ Lviv University of Trade and Economics, Ukraine.

E-mail: kotuha1@ukr.net
} 


\section{Introduction}

The conditions of globalization put forward new threats to the existence of the traditional way of life. At present, poverty of the population, considerable property differentiation, lack of middle class, low level and quality of life in the Ukrainian society are especially dangerous and threatening crisis phenomena of socioeconomic character in Ukrainian society. This fact confirms the statistics of criminal offenses in the sphere of providing the basis of state security, as well as in the field of providing public services, economic activities, and property crimes. Thus, all this, undoubtedly, actualizes the study of the issue of ensuring Ukraine's state security from socio-economic threats.

Providing state security is in the sight of a large number of leading scientists. G. P. Sitnik's scientific intelligence touches upon the state administration in the sphere of national security, G. Novitsky - study of the theoretical and legal principles of providing state security of Ukraine, V. Yu. Bogdanovich - analysis of the problems of the state military security. The works of M. Sungurovsky and V. A. Lipkan are devoted to theoretic and methodologic principles of the system of ensuring state security. V.P. Gorbulin and A. B. Kachinsky considered the issues of strategic planning in the field of state security. G. O. Ponomarenko paid attention to the administrative issues of ensuring the internal security of the state. To the block of economic security and counteraction to economic crime, a big number of works by O. E. Koristin, V. T. Belous, V. V. Kovalenko are devoted. Social determinants of national security were considered by A. L. Balanda, problems of social security - by L. I. Ilchuk, O. O. Davidov.

We have to note that in this case, the study of the crisis phenomena of the socio-economic nature itself and their impact on the providing of state security has not been given sufficient attention.

Therefore, the purpose of the article is to carry out a study on the methodology of the impact of crisis phenomena of a socio-economic nature on the state of ensuring the state security of Ukraine in order to develop a model of the emergence and impact of crisis phenomena of a socio-economic nature on the state of its security.

\section{Legal principles of identification of crisis phenomena of socio-economic character}

According to the Law of Ukraine "On National Security of Ukraine", "national security of Ukraine" defines "the security of state sovereignty, territorial integrity, democratic constitutional order, and other national interests of Ukraine from real and potential threats."

The national interests of Ukraine set the vital interests of man, society, and the state, the realization of which is ensured by the state sovereignty of Ukraine, its progressive democratic development, as well as safe living conditions and welfare of its citizens. Threats to the national security of Ukraine are the phenomena, trends, and factors that make it impossible or complicate or make it impossible or difficult to realize the national interests and preserve the national values of Ukraine (On National Security of Ukraine, 2018).

At the same time, it is possible to note that the legislator is evolving in certain specified terms. The most significant change came from the definition of "national security", where state sovereignty, territorial integrity, and democratic constitutional system have become paramount in the interests of national interests (The National Security Strategy, 2015).

Under the state security, we understand the security of the state sovereignty, territorial integrity, and democratic constitutional order and other vital national interests from real and potential threats of non-military character (On National Security of Ukraine, 2018).

Crisis phenomena of socio-economic nature create threats to the providing of material, intellectual, and spiritual values. In the system of providing state security, they gain especially significant value.

Social security integrates all kinds of security, such as economic, political, military, information, ecologic, scientific and technological, and others. The present situation proves that the most dangerous is the synergistic synthesis of economic and social danger, namely, the impact of the economic crisis on social security. In this case, there are crisis phenomena of a socio-economic nature.

The main threats to national interests in the socioeconomic sphere are:

- the inconsistency of the programs of reforming the country's economy and the results of their implementation to certain social priorities;

- ineffectiveness of the state policy on increasing the labour incomes of citizens, overcoming poverty, and balancing productive employment of the able-bodied population;

- the crisis of the system of health protection and social protection of the population, as a result of which there is a dangerous deterioration of the health of the population;

- the spread of social diseases, in particular, drug addiction and alcoholism;

- worsening of the demographic crisis, strengthening of the ageing trend of the nation;

- reduction of the opportunities for obtaining a quality education by representatives of the poor class of society; - manifestations of moral and spiritual degradation of society;

- the growth of the child and adolescent homelessness, vagrancy;

- uncontrolled migration processes, depletion from the country of good-skilled personnel;

- reduction of population and its natural increasing. 
The following threats may be added to this list:

- increasing the number of people living below the poverty line;

- significant property differentiation of the population (increasing the financial gap between the incomes of the poor and wealthy citizens);

- a small percentage of the population forming the middle class of the state;

- the growth of social tension in society, the readiness of the population to take active action, increase of the probability of mass riots.

Therefore, in the system of ensuring state security, it is necessary to develop and implement effective mechanisms for the state regulation of these phenomena.

\section{The methodology of studying the nature of crisis phenomena of the social and economic character}

Recent crises in the countries of Western Europe and North Africa, which are social in nature, show that the most acute, mass, and socially dangerous crisis phenomena are phenomena caused by low level and quality of life of the population and unsolved social problems. They are the basis of conflict situations that arise between people of the country and the authorities. That's, the most expedient and relevant is the study of the crisis phenomena of social and economic nature.

Crisis phenomena of social and economic character are considered in various scientific theories. For example, the theory of the social and economic development of the regions considers the crisis phenomena of a social and economic nature as threats hindering economic development (Kuznetsov, 2004). Sociology considers these phenomena as threats to social protection of the population (Maistro, Protsiuk, 2010), conflictology - solving social conflicts on social and economic basis (Herasina, Panov, Osipova, 2002), national security - prevention and elimination of emergencies of social nature on social and economic basis (Lipkan, 2009). However, the only approach is practically not presented today.

Consequently, based on the above, it can be noted that the most negative effects on the state of ensuring state security in the social and economic sphere are crises. In many languages, the crisis means different phenomena; in general, there is a threat. In Chinese, the term "crisis" means two words - "danger" and "opportunity". The crisis in Greek (krísis - decision, turning point) - a turning point, a difficult transition state, exacerbation, a dangerous unstable situation.

For social and economic systems, N. Stetsyuk provided the appropriate definition: "the crisis is a natural process (if not imposed from the external environment) faced by any social and economic system, it represents the state of instability, generated external and internal factors that threaten the viability of the system in the environment"
(Stetsiuk, 2006). Consequently, in this definition, the presence of a threat is the central position.

Currently, scholars divide the crisis into three main groups for the causes of the emergence (Kukushkyn, 2001): natural crises, due to natural conditions of life and human activity; social crises that arise in the process of social relations in society; environmental crises caused by natural conditions, due to human activities.

Crisis phenomena of a social and economic nature refer to social crises, so let's consider the classification of social crises in the future. According to the structure of the socio-economic system, social crises are distinguished by economic, social, political, economic, psychological, technological, etc. According to our study, the analysis of economic and social crises is more appropriate as the crisis phenomena of a socioeconomic nature are on the brink of collisions between economic and social crises.

Economic crises reflect sharp economic disputes in social and economic systems, that is, in the processes of production and sales of goods and services. By classical definition, economic crises include only overproduction of goods that do not have sales due to the low solvency of the population (over-production crises). In our time, under the definition of economic crisis, first of all, we understand the global financial crises (Mamalui, Hrytsenko, Hrytsenko, 2006). Variants of economic crises also include stock, financial, currency, and other crises. Consequently, economic crises concern, first of all, economic processes in social and economic systems, but thus the state of human life (solvency) is also taken into account.

Social crises arise when aggravation of clashes and contradictions between social groups. In social and economic systems, these are: employees and managers of organizations, trade unions and entrepreneurs, workers of enterprises and state authorities, etc. That is, social crises, above all, are associated with conflicts and conflict situations (Lantsov, 2008). The causes of social crises can be both economic crises and other areas of life (political, environmental, technological, and other problems of society).

Thus, based on the above analysis of economic and social crises, it is possible to note that the crisis phenomena of a socio-economic nature relate, first of all, to human life and the level of threats that these phenomena can cause. The result is a conflict situation (social conflict) on an economic background that threatens state security.

Economic and social crises lead to the emergence of crisis phenomena of social and economic nature in the form of deteriorating living conditions and the emergence of conflict situations (social conflicts). The social and economic system is a complex holistic system, in which all elements are interconnected, therefore, the crisis phenomena of social and economic nature can lead to today's crises, first of all, to the social 
ones. However, the emergence of environmental crises due to crisis phenomena of socio-economic nature is also possible, because by their nature they are generated by people. Natural crises do not depend on human activity but global warming causes natural disasters, which are the result of the technological activity of mankind.

Thus, we can conclude that the main crisis phenomena of socio-economic nature are: high poverty rate of the population; significant property differentiation of the population; social inequality; the absence of a clearly pronounced middle class.

\section{Model of the emergence and impact of crisis phenomena of socio-economic character on the state of state security}

Figure 1 shows the model of the emergence and impact of crisis phenomena of socio-economic nature on the state of state security.

In an era of globalization, there is an increasingly tangible impact of the external economic environment on the Ukrainian economy. The global financial crisis has revealed the Government's failure to effectively counter external economic threats. The financial assistance of the International Monetary Fund requires the Government of Ukraine to reduce the cost of social security for the population, increase tariffs for communal services, etc., which causes a worsening the level and quality of life of the population and numerous protests. The requirements imposed by the international community on the export of Ukrainian goods, raw materials and services, prices for energy resources procured by Ukraine, have a negative impact on the economy and contribute to the emergence of crisis socio-economic events.

Ineffective governmental activities and geopolitical influence on Ukraine have a negative impact on the socio-economic system, namely on the production, distribution, exchange, consumption of material and other goods.

Economic and social crises lead to a high level of poverty, ineffective social security of the population, significant property differentiation of the population, high levels of corruption, and lack of middle class. As a result, there is social tension in society. It is a definite indicator of the level and quality of life of the population. The task of executive authorities and local self-government is to monitor the level of social tension and take appropriate measures to reduce it in order to prevent the emergence and reduction of the level of threats to state security of socio-economic nature.

Threats can be manifested in the deviant way of life of the population (drunkenness, drug addiction, HIV transmission, divorce, suicide, migration of the population, etc.), high levels of crime (quackery, fraud, theft, banditry, terrorism) and the emergence of social conflicts (protest rallies, mass disorder, revolution, armed conflict). These threats lead to a decrease in the life expectancy of the population, a high mortality rate, and a low fertility rate, that is, before the demographic crisis in Ukraine.

Today, one of the main threats to state security is the demographic crisis in Ukraine. Until recently, threats to national security were more explored in the military and foreign policy spheres and related to military conflicts between countries. But world events prove the urgency of threats to the state's internal security, namely, the low level and quality of life of the population and social tensions that affect the demographic factor. L. Kostrovets argues that the mode of population reproduction, its quantitative and qualitative composition can stimulate or inhibit the emergence and development of internal and external social conflicts, to be a catalyst for the separatist aspirations of a part of the population, that is, to carry out a destructive influence on the state of the state security, even if a stable international situation.

The developed model shows that today the study of threats to state security, which arose on the socioeconomic basis, should have special attention. The multifaceted social and economic processes in Ukraine, the deterioration in the level and quality of life of the population, social tensions lead to deformation and destruction of public life, political stability in the state, and require public authorities to take more into account the internal policy of the socio-economic factor in state security and develop state mechanisms of counteraction to the crisis phenomena of socio-economic nature.

Thus, it may be noted that at the present day in Ukraine, publicauthoritiesneed to introducemechanismsto counter crisis phenomena of socio-economic character. During the development and implementation of these mechanisms, there are contradictions, namely, socioeconomic crisis phenomena are the consequences of the economic crisis in the social sphere, they are expressed in an alarming state of vital activity of the population, leading to conflict situations. Conflicts can be resolved by improving the living conditions of the population. It is impossible for Ukraine because the economy is in a crisis situation; there are no funds for social programs. Government actions, in this case, are aimed at the development of the economy and not the social protection of the population. In addition, the international community, which helps Ukraine in economic development (International Monetary Fund, etc.), sets out requirements for reducing social security, not to mention its increasing.

\section{Conclusions}

On the basis of the mentioned facts in the article, it is possible to draw conclusions.

1. The emergence of crisis phenomena, containing the socio-economic component, requires the government to take timely and effective management decisions. 


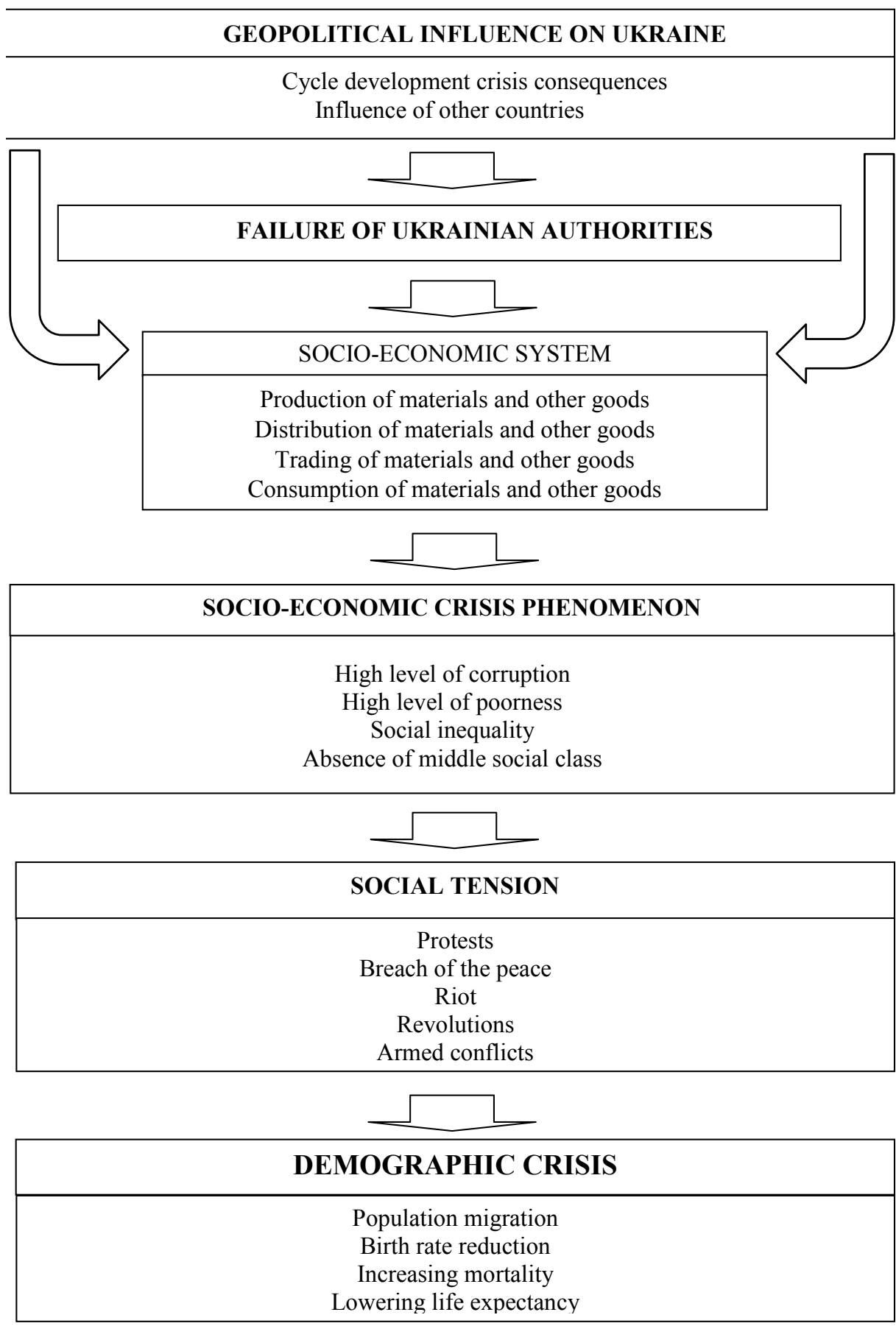

Figure 1. Model of the emergence and impact of crisis phenomena of socio-economic character on the state of state security

Such phenomena occupy a central place among the threats to society in the system of ensuring state security.

2. The main crisis phenomena of socio-economic character in Ukraine are identified as high levels of corruption, a high level of poverty, a substantial population differentiation of property, a social disparity and middle-class lack.

3. Analysis of crisis phenomena shows that the most acute, mass, and socially dangerous crisis phenomena are those caused by low living standards and unsolved social problems. They are the basis of grave social conflicts between people and authorities.

4. The developed model of the emergence and impact of the crisis phenomena of socio-economic nature on state security shows that today the research of threats to state security, which arose on the socio-economic basis, deserves special attention. The most expedient and relevant is the study of the crisis phenomena of socioeconomic nature and development mechanisms of state regulation of these phenomena. 


\section{References:}

Herasina, L. M., Panov, M. I., Osipova, N. P. (2002). Konfliktolohiia [Conflictology]. Kharkov: Pravo. (in Ukrainian) Kukushkyn, S. (2001). Antikrizisnoe upravlenie [Crisis management]. Ulyanovsk: UlHTsU. (in Russian)

Kuznetsov, A. O. (2004). Sutnist sotsialno-ekonomichnoho rozvytku: teoretyko-metodolohichnyi aspekt [Essence of social and economic development: theoretical and methodological aspect]. Bulletin of the State Service of Ukraine, vol. 1, pp. 45-46.

Lantsov, S. (2008). Polytycheskaia konflyktolohyia [Political conflictology]. St. Petersburg: SPb : Piter (in Russian) Lipkan, V. A. (2009). Natsionalna bezpeka [National security]. Kiev: KNT. (in Ukrainian)

Maistro, S. V., Protsiuk, S. L. (2010). Sotsialnyi zakhyst ekonomichno aktyvnoho naselennia v umovakh hlobalizatsii [Social protection of economically active population in the conditions of globalization]. State building, vol. 1. Retrieved from: http://nbuv.gov.ua/j-pdf/DeBu_2010_1_12.pdf (accessed 10 August 2018)

Mamalui, O. O., Hrytsenko, O. A., Hrytsenko, L. V. (2006). Osnovy ekonomichnoi teorii [Foundations of economic theory]. Kiev: Yurinkom Inter. (in Ukrainian)

Stetsiuk, N. M. (2006). Antikrizisnoe upravlenie [Crisis management]. Khabarovsk: DVHUPS. (in Russian)

Ukaz Prezydenta Ukrainy vid 26.05.2015 r. № 287/2015 «Pro Stratehiiu natsionalnoi bezpeky Ukrainy» [Decree of the President of Ukraine 26.05.2015. № 287/2015 «On the Strategy of National Security of Ukraine»]. Retrieved from: http://zakon5.rada.gov.ua/laws/show/287/2015 (accessed 10 August 2018)

Zakon Ukrainy «Pro natsionalny bezpeky Ukrainy» [The Law of Ukraine «On National Security of Ukraine»]. Retrieved from: http://zakon1.rada.gov.ua/laws/show/964-15 (accessed 10 August 2018) 